\title{
IgM Monoclonal Gammopathy of Undetermined Significance
}

National Cancer Institute

\section{Source}

National Cancer Institute. IgM Monoclonal Gammopathy of Undetermined Significance. NCI Thesaurus. Code C150566.

Monoclonal gammopathy of undetermined significance defined by a serum Ig M paraprotein concentration less than $30 \mathrm{~g} / \mathrm{L}$; bone marrow lymphoplasmacytic infiltration of less than 10\%; and no evidence of anemia, constitutional symptoms, hyperviscocity, lymphadenopathy, hepatosplenomegaly, or other end-organ damage that can be attributed to the underlying lymphoproliferative disorder. It is a precursor condition that may progress to lymphoplasmacytic lymphoma/ Waldenstrom macroglobulinemia, other B-cell neoplasms, or primary amyloidosis. Progression to plasma cell myeloma occurs rarely, if at all. (WHO 2017) 